Отримано: 24.10 .2020 p.

Прорецензовано: 28.10.2020 p.

Прийнято до друку: 02.11.2020 р.

e-mail: cerkas@ukr.net

DOI: $10.25264 / 2409-6806-2020-30-67-77$
Атаманенко В. Первинні поборові реєстри як історичне джерело (на прикладі міст Волині середини XVI ст.). Наукові записки Національного університету «Острозька академія». Серія «Історичні науки». Острог, 2020. Вип. 30. С. 67-77.

\title{
Віктор Атаманенко
}

\section{ПЕРВИННІ ПОБОРОВІ РЕССТРИ ЯК ІСТОРИЧНЕ ДЖЕРЕЛО (НА ПРИКЛАДІ МІСТ ВОЛИНІ СЕРЕДИНИ ХVІ СТ.)}

У статті розглянуто окремі джерелознавчі характеристики первинних поборових реєстрів 15691570 р. на прикладі міст Волині. Дана категорія джерел служсила основою для створення узагальнюючих податкових документів для окремих адміністративних одинииь Речі Посполитої, через що вони найчастіше використовуються для дослідження соціально-економічної проблематики. Це стало однією з підстав невисокого рівня збереження первинних матеріалів, щь збільшує їх важливість як історичного джерела.

Ключові слова: джерелознавство, описово-статистичні джерела, ранньомодерні міста Волині.

Viktor Atamanenko

\section{PRIMARY TAXES REGISTERS AS A HISTORICAL SOURCE (ON THE EXAMPLE OF THE VOLYNIAN CITIES IN THE MIDDLE OF THE XVI CENTURY)}

Much of the work on the problems of socio-economic history (including urban issues) of Volhynia in the middle and second half of the XVI century are based on state tax documents. Since the Lublin Union, there are very few such sources. Besides, they did not cover a significant number of urban settlements. A higher level of regularity of taxation and greater control resulted in better preservation of the so-called [taxation] registers. For Volyn, this can only be said about the two-decade period after the Lublin Union. The chronological representativeness of this group of sources cannot be considered satisfactory. This applies to the least used and practically not represented by researchers and archaeographers in circulation in the entirety of the primary registers. The complex of such sources requires the implementation of their source characteristics as a separate variety (including specific historical issues) and in comparison with the already used tax documentation, mostly generalized by administrative-territorial units. State fiscal documentation consisted of several levels of sources. The first consideration of state revenue cases for the incorporated territories was already included in the resolution of the Lublin Sejm in 1569, where it occupied almost the largest volume compared to other issues and was also issued as a separate Taxation Universal. Thus, for the first time, the Ukrainian lands included into Poland received a well-developed basis for taxation. When collecting a tax, the owners or their administration created special lists - primary tax registers. All surviving primary tax registers date back to the first decade after the Lublin Union.Primary tax registers for 1569-1570 survived only for a few Volyn cities. These are Buremel, Zvinyhorod, Zviahel, Koblin, Nesukhoizhi, Turiisk, Ostrozhets. Compared to the total register of 1570, this number of recorded cities is insignificant. But this is offset by the nature of the information. The primary tax documentation contains a personal record of the population with an indication of the tax grounds for each person. In some cases (for households) they contain evidence of the gender structure of the population. Thus, for demographic research, such sources have a number of advantages.

Key words: source studies, descriptive and statistical sources, cities of Volyn of the early modern period.

Значна частина праць, присвячених проблемам соціально-економічної історії (в тому числі, й урбаністичній тематиці) Волині, та й інших українських земель, середини та другої половини XVI ст. спираються на документи державного оподаткування. 3 часів до Люблінської унії подібних джерел збереглося вкрай мало. До того ж вони не охоплювали значного числа міських поселень. Вищий рівень регулярності оподаткування та більший контроль мали наслідком краще збереження т. зв. поборових реєстрів, які й фіксували вибирання податку і зберігалися серед документів Коронного 
скарбу. Для Волині про це можна говорити лише для дводесятирічного періоду після Люблінської унії. Хронологічна репрезентативність цієї групи джерел не може вважатися задовільною, оскільки Архів давніх актів у Варшаві постраждав у роки Другої світової війни, коли, можливо, було втрачено й частину податкової документації Речі Посполитої. Це стосується й найменше використовуваних і практично невведених дослідниками та археографами до обігу в усій повноті первинних реєстрів. Комплекс таких джерел вимагає здійснення їх джерелознавчої характеристики як окремого різновиду (в тому числі і на рівні конкретно-історичної проблематики), так і в порівнянні із вже використовуваною податковою документацією переважно узагальнюючого за адміністративно-територіальними одиницями характеру. Розгляд цих аспектів і $є$ завданням даної статті.

У літературі податкова документація знайшла відображення в діяльності українських та польських археографів та істориків з кінця XIX ст. Привертала вона увагу й при дослідженні ряду проблем конкретно-історичної проблематики. Первинні поборові реєстри волинських міст опубліковані лише частково (Дубно, Ковель, Літовиж, Несухоїжі, Острог, Старокостянтинів, Турійськ) [2 - 4; 8; 19$]$.

В літературі висловлюються відмінні погляди щодо інформаційної якості різних категорій податкових документів кінця XVI - першої половини XVII ст. Так, О.І. Баранович вважав, що за відсутності інших джерел, крім поборових реєстрів, доводиться їх використовувати [7, с. 7]. В окремих працях висловлювались погляди щодо якості зафіксованої в поборових документах інформації. Я.П.Кісь вважав, що такі джерела «часто неповні й неточні, однак, при відсутності інших, єдині» і притримувався точки зору про те, що на більшу увагу заслуговують люстрації, які доповнюються «нечисленними інвентарями» і свідченнями актових книг судово-адміністративних установ [13, с. 90]. Дослідник зробив висновок, що, відповідно, і зроблені на їх підставі підрахунки страждають неточністю та занижують реальний стан речей $[13$, с. 90,93$]$. До близьких висновків прийшов і М.Г.Крикун при оцінці інформативності джерел вивчення історико-демографічної проблематики. На його думку, визначення чисельності населення в Україні, спираючись на більш-менш вірогідні документи, можливе лише для часу протягом першої половини XVII ст. Це твердження відображає недовіру до джерельних якостей поборових реєстрів 70 - 80-х pp. XVI ст. Говорячи про весь час перебування Правобережної України в складі Речі Посполитої, дослідник наголошує і на причинах подібної ситуації. Вони були пов'язані з тим, що ці джерела спиралися на ніким не контрольованих свідченнях власників маєтків, у зв' язку з чим могли більшою чи меншою мірою спотворювати дійсний стан оподатковуваних категорій залежного населення, що й негативно позначалося на повноті та вірогідності інформації $[15$, c. 77$]$. Незважаючи на відзначені недоліки, М.Г.Крикун вважає їх достатньо репрезентативними в територіальному відношенні, а їх використання робить можливим вивчення значного кола проблем $[15$, c. 77$]$. Не згадуючи характеристик дотичних до українських теренів різних категорій описово-статистичних джерел, які давалися польськими дослідниками починаючи з А. Павінського та О. Яблоновського, на можна не вказати на сучасну активізацію досліджень поборових реєстрів, в тому числі при використанні комп'ютерних технологій та створення їх електронного видання [25 28]. В усіх розглянутих випадках увагу дослідників привертали реєстри сумарні (сумарії, сумаріуші), які стосуються крупних адміністративно-територіальних одиниць Польщі та Речі Посполитої. Не можна не нагадати й незначність археографічного опрацювання реєстрів первинних, які стосуються окремих маєткових комплексів. Воно стосується лише декількох латифундій Волині $[2-4 ; 8 ; 19 ; 21]$.

Вся сукупність поборової документації мала складний характер. Вона включала в себе матеріали первинного збору податку, які стосувалися окремих маєтностей та їх узагальнення на рівні окремих адміністративних одиниць держави. Звідси й можливі втрати серед неї під час активного побутування, тобто до реформи $1629 \mathrm{p}$.

Основою для вивчення господарського, а також соціального, розвитку волинських міст служать, в першу чергу, різні категорії джерел описово-статистичного характеру. Але рівень їх збереженості за період другої половини XVI ст. - першої третини XVII ст. вкрай нерівномірний. Для всієї території Волині вони збереглися лише для 70 - 80-х років XVI ст. Дана обставина мала наслідком значний рівень їх археографічного освоєння (починаючи з 70-х рр. позаминулого сторіччя) $[1 ; 7 ; 30]$ та пов'язаної з цим характеристики інформативних можливостей цих джерел $[30 ; 7 ; 12 ; 14-17 ; 18]$. Специфіка інформації в таких джерелах мала наслідком їх використання не в усій інформативній повноті, а часто - для ілюстрації становища окремих категорій населення, характеристики окремих міських поселень та визначення історико-демографічних характеристик регіонів. Податкова доку- 
ментація й на сьогодні залишається чи не найчастіше (більшою чи меншою мірою) використовуваною в конкретно-історичних дослідженнях.

Уся сукупність податкових джерел кінця XVI - першої третини XVII ст. за об'єктом оподаткування поділяється на дві групи. Люблінський сейм 1569 р. запровадив для інкорпорованих українських земель побор, який збирався з усього непривілейованого населення від володіння нерухомістю в містах і заняття ремеслом чи промислами в містах і селах, а також за користування землею з селян та міщан. Отже, він був складним за структурою податком. Окремо виділялися особи, котрі не володіли нерухомістю, але обкладалися податком (вищим - люзні, гультяї). Поголовний податок накладався на єврейське населення, але свідчення про нього на етапі опрацювання поборових даних включалися до загальних територіальних показників. Отже, окреслений терміном “побор" податок фактично складався з відмінних платежів. 3 точки зору документального оформлення результатів збирання податку на рівні державної скарбниці він частіше за все був єдиним. Первинні реєстри (квити та рекогніції), створювані власниками чи їх представниками, називали податок по-різному: посеребщина, поголовне, подимне, побор, плат поборний, ланівщина [23, Арк. 53, 64, 87, 104, 154, 262, 284, 638 та ін.].

Регулярні татарські напади останньої чверті XVI ст. (1575, 1577, 1578, 1588, 1593 рр.), від яких потерпали саме українські землі, призводили до державної та приватної практики звільнення маєтків від сплати податків, що передбачалося й сеймовими ухвалами. Більше того, страшні спустошення Волині, де в першу чергу та найсильніше страждали ії південні землі - Кременецький та частково Луцький повіти, під час нападів 1577 та 1578 рр. спричинили триваліші за визначені поборовими універсалами терміни звільнення від сплати податків [5; 22, Арк. 2 - 52, 328 - 338, 558 - 559 зв.]. Менші можливості для контролю над повнотою збирання податків давала і наявність значної кількості розлогих латифундій. Спустошення мали наслідком зменшення населення, особливо помітного на прикладі південних теренів Волині, що знаходило відображення і в поборових реєстрах. Дана обставина могла створювала можливості й для приховування дійсного стану маєтків. Звільнення від сплати податків могли викликати й пожежі. Відомо про пожежі в Володимирі $(1560,1563,1564$, 1568, 1573, 1632, 1641 рр.), Луцьку (1571, 1580, 1582, 1583 двічі, 1617, 1633 рр.), Дорогостаях (1573, 1585 р.p.), Базалії (1579 р.), Серкизові (1587 р.), Литовижі (1588 р.), Береську (1591р.), Збаражі (1591 р.), Базарі (1591 р.), Степані (1591 р.), Новому Вишнівцю (1596 р.), Старокостянтинові (1599 р.), Острозі (1604, 1634 та 1635 рр.), Камені (1607 р.), Ковелі (1624 р., двічі), Вишгородку (1626 р.), Олиці (1628, 1629, 1630 рр.), Степані (1629), Несухоїжах (1630р.), Рівному (1634 р.), Тайкурах (1634 р.), Соколі (1634 р.), Маначині (1635 р.), Дорогобужі (1635 р.), Кременці (1635 р.), Рильську (1635р.), Клевані (1635 р.), Хлапотині (1645) [10, 417]. На основі свідчень сумарного поборового реєстру 1589 р. можна говорити про пожежу в Дубно, в якій згоріла половина міста і що вона відбулася в проміжку від 1585 до 1593 р. [24, k. 6v.].

Державна фіскальна документація складалася з кількох рівнів джерел. Приводом же до вибирання податку був затверджений сеймом поборовий універсал. Він визначав норми оподаткування для різних категорій населення чи поселень, умови звільнення від сплати та визначав поборців. Вивчення обставин створення джерел статистичного характеру спирається загалом на розгляд підстав збирання інформації та осіб, які до цього залучалися. Перший для інкорпорованих територій розгляд справ державних прибутків було включено вже в ухвалу Люблінського сейму 1569 р., в якій він займав чи не найбільший обсяг порівняно з іншими питаннями, а також оформлено окремим поборовим універсалом [31, s. 95 - 98, 101 -106]. Відтак, включені до складу Польщі українські землі вперше одержали достатньо розроблену підставу вибирання податків. При вибиранні податку власниками чи їх адміністрацією створювалися спеціальні списки - поборові реєстри (іх необхідно відрізняти від створюваних у подальшому реєстрів-сумаріїв, для чого варто вживати термін “первинні”). Процес передачі зібраного податку в руки визначеного сеймом поборці супроводжувався творенням таких різновидів документації, як квити та рекогніції. Вони були тотожними за змістом і були реєстрамирозписками про передачу податкових сум. Квити та рекогніції про сплату податків з волинських маєтностей майже не збереглися. Всі вцілілі первинні поборові реєстри припадають на 70 - 80 pp. XVI ст. В окремих випадках вони збереглися у складі родинних архівів (наприклад, реєстр Острозької волості 1604 р. [21, с. 105 - 184]). Саме на підставі первинних реєстрів поборці створювали підсумковий документ, сумарій (сумаріш). Він структурувався за окремими повітами того чи іншого воєводства та маєтковими комплексами в їх межах. До них додавалися свідчення про осіб, які не сплатили податок. На основі територіальних підсумкових реєстрів скарбовими урядовцями створю- 
валися загальнодержавні сумаріуші, які містили дані винятково за адміністративними складниками Речі Посполитої.

Питання, яке довелося одразу ж розв’язувати дослідникам стосовно податкової документації, було пов'язане з повнотою та репрезентативністю. Його і в подальшому продовжували піднімати та розглядати, але майже винятково в руслі історико-демографічної проблематики. Основний висновок наголошує на незамінності податкових матеріалів 3 точки зору масовості та територіального охоплення [29, s. 576]. Але в їх сукупності з даної точки зору перевага належить подимним реєстрам, до появи яких (1629 р.) вірогідних джерел стосовно залюднення українських земель не створювалося [14, c. 71]. Виходячи з цього, запропонована відкривачами для історичної науки податкових матеріалів О. Яблоновським та А. Павіньським реконструкція залюднення, структури населення та земельної власності різних складових частин Речі Посполитої, яка спиралася на поборові реєстри, перш за все, за 1578 р. [29, s. 581], хибує на неточність, особливо зважаючи на зауваження самих ії творців стосовно відсутності для українських земель настільки ж якісного реєстру, яким для етнічних польських земель був саме реєстр 1578 р. Більш-менш цілісна й повна оцінка джерел статистичного характеру XVI ст. вимагає вивченості ряду проблем конкретно-історичного плану, в першу чергу, історії (та руху) окремих володінь. Низька вірогідність цих документів стосовно історико-демографічної проблематики зауважувалася і пізніше [14, с. 170]. При цьому при протиставленні реєстрів подимних та поборових традиційно використовувався штамп про практичну невивченість останніх [17, с. 170; 29, s. 576].

Таким чином, в історіографії одним з основних недоліків поборових реєстрів вважається неповнота свідчень. До їх причин можна віднести характерне не тільки для XVI - XVII ст. заниження чи приховування підстав оподаткування, наявність звільнень від сплати податку, неможливість перевірки даних, наданих платником, а також цілком логічні підозри стосовно сумління поборців [6, c. 49 - 58; 29, s. 577 - 580]. На думку І. Гейшторової, навіть реєстри за роки максимальної податкової точності не можуть бути цілком незалежними від можливості надуживань хоча б через те, що якась частина платників запізнювалася зі сплатою [29, s. 579]. Зважаючи на незбереженість для Волині, як вважають, найбільш повного реєстру 1578 р. (правда, для українських земель і він був би неповним через припадаючий на цей час пік спустошень в результаті татарських нападів), за основу вивчення історико-демографічних питань слід брати реєстр 1583 р. [30] та значною мірою, якщо не повністю, 1589 р. [24] (саме напередодні, в 1588 р., було ухвалено поборовий універсал, який започаткував практику вибирання побору на основі даних за 1578 р. [29, s. 581 - 582]). Незначна частина волинських первинних поборових документів за 70 - 80-ті pp. XVI ст. збереглася [23]. 3 часом, особливо в першій половині XVII ст., точність поборових реєстрів суттєво погіршується [29, s. 582], що могло бути однією з підстав податкової реформи в Речі Посполитій. Стосовно Волині вони й не збереглися, за винятком копій первинних документів, які в шляхетських маєтках відігравали роль господарських документів внутрішньодоменіального значення. Одним з можливих на сьогодні шляхів оцінки якості інформації поборових реєстрів є доволі традиційний спосіб ії порівняння зі свідченнями інших, схожих за характером, джерел. Зрозуміло, що при такому підході при наявності навіть незначної інформації, яку неможливо перевірити, вірогідність поборових реєстрів певною мірою викликатиме сумніви. Тому може йтися тільки про можливість поширення перевірених даних і висновків про їх точність на всі дані того чи іншого реєстру, тобто про можливості і межі використання вибіркового методу. Джерелами, які в першу чергу можуть заслуговувати на увагу при даних обставинах, $є$ інвентарні описи маєтків. Характеристика інвентарів як історичного джерела, незважаючи на їх недостатню вивченість, дає змогу вважати їх у вищій мірі точними та репрезентативними за багатьма параметрами $[7$, с. 5; 9, с. 94; 18, с. 91]. Не можна залишити поза увагою і групу, яку умовно можна назвати первинними поборовими документами (чи реєстрами) і яка в повній мірі не стала навіть об’єктом черпання інформації.

Коли говорять про вищу вірогідність реєстрів подимного порівняно з поборовими реєстрами, як правило, вказують на суттєву різницю в результатах заснованих на них підрахунків чисельності населення. Вони дійсно відмінні більш, ніж вдвічі: за обрахунками О. Яблоновського, здійсненими на основі поборової документації, на Волині проживало 293780 осіб [30, s. 56], а за обчисленнями, заснованими переважно на тарифах подимного - 655660, а то й не менше за 770000 [7, с. 19; 14 , с. 80]. Але при цьому не беруться до уваги значні зміни в соціально-економічному житті на українських землях, в тому числі й на Волині, які впливали на рівень залюднення та демографічну поведінку. 
Крім того, використовувані поборові реєстри відображають становище після ряду спустошливих татарських нападів і не фіксують звільнених від сплати податку населених пунктів та, відповідно, відображають чи не найбільше відхилення від реального стану речей, що не може не привести до висновку про суттєво більшу кількість населення на час створення поборових реєстрів. Зрештою, між часовими моментами визначення чисельності населення Волині на основі цих категорій джерел лежить відтинок у півсторіччя відносно стабільнішого життя (незважаючи на спустошливі татарські напади 1593 та 1617 - 1618 рр.), протягом якого, наприклад, кількість волинських міст зросла майже втричі $[11$, с. $42,69,88]$, правда число реально існуючих було меншим [11, с. 42, 69, 88]. Отже, зростання приблизно вдвічі чисельності міст, яке, без сумніву, не могло відбутися в аграрному суспільстві без інтенсивного розвитку сільської округи (яка була однією з підстав збільшення населення міст), загалом корелює із коефіцієнтом зростання чисельності населення, визначеного на основі реєстрів поборових та подимних. 3 іншого боку, коли стосується джерел 3 польських теренів, теоретично більш придатні для історико-демографічних досліджень реєстри подимного дають нижчі порівняно 3 поборовими реєстрами результати обрахування чисельності населення [29, s. 584 - 585].

Як уже згадувалося, одним із способів показу вірогідності подимних реєстрів, реалізованих М.Г. Крикуном, є порівняння його свідчень $з$ даними люстрацій та інвентарів [16, с. 73 - 77]. Це стосується не тільки Волині, але й Наддніпрянщини, Поділля та Белзщини. У переважній більшості випадків для XVII ст. співставлення здійснювалося переважно на прикладі латифундій, інвентарі яких для попереднього часу практично не збереглися. Відтак, верифікація поборових реєстрів не може вважатися настільки ж строгою, як реєстрів подимного. Справа, зрозуміло, не в розмірі землеволодіннь, поселення з яких беруться для дослідження, а в тому, що практично всі описи волинських маєтків 60 - 90 pp. XVI ст. придатних для співвіднесення зі свідченнями податкової документації, створювалися у випадках проведення маєткових операцій і збереглися у складі актових книг судовоадміністративних установ. Дуже часто це частини маєтків, які складно точно співвіднести з тим чи іншим маєтком як об'єктом державного оподаткування. Складний характер оформлення таких інвентарів, з іншого боку, гарантував високий рівень надійності та вірогідності.

Порівняння вже самого переліку маєтків на основі свідчень поборових реєстрів та інвентарних описів показує неповноту перших в усіх відомих їх варіантах (1570, 1577, 1583 та 1589 рр.). Пояснити це можна як неоподаткуванням спустошених поселень, так і ухилянням від сплати побору. Про значну спустошеність Волині на цей час свідчать хрестоматійні факти звільнення багатьох волинських шляхтичів від сплати податків зі своїх маєтків та заява поборці Ф. Рудецького вже в реєстрі 1577 р. з відзначенням несплати побору через спустошеність маєтків всією шляхтою підгоринською, кременецькою та значною частиною луцької та володимирської [30, s. 78]. Переважала, скоріше за все, перша обставина, що аж ніяк не змінює факту недостатньої репрезентативності поборових реєстрів. Як відомо, поборові реєстри по-різному характеризують об'єкти оподаткування, маючи підставою відповідні розміри землі (лан, волока, дворище, дим, різні категорії городників, підсусідків тощо). Узгодження таких розгалужених характеристик для окремих випадків можна здійснити, але для значної сукупності маєткових одиниць воно вимагає уніфікованої трансформації даних. Її підставою може бути прийняте сучасниками співвіднесення різних категорій господарств. Чи не найбільш повне охоплення різних категорій господарств (в даному випадку сільських, але характерних i для міст) дано в інвентарі с. Угринів, де дворище прирівнювалося до волоки, півволоки (а отже і півдворища) - до диму, городники без орної землі ошацовуються у 5 копах гр. Скоріше за все, таке співвідношення, хоч і представлене в приватновласницькому документі, відображало напрацьовану роками практику державних, в тому числі й податкових, інституцій.

До нашого часу збереглися і введені до наукового обігу через археографічне опрацювання поборові сумарії 1570, 1577, 1583 рр. та свідчення про міські податки 1589 р. [30]. Крім того, опубліковано окремі найдавніші первинні поборові реєстри таких міст, як Турійськ, Несухоїжі, Дубно, Остріг, Литовіж, Старокостянтинів (див. вище). Але лише перші два документи стосуються середини XVI ст. Залишаються невиданими первинні реєстри середини XVI ст. таких міських поселень, як Буремель, Звинигород, Острожець, Коблин та Звягель, частина належних якому сільських маєтків розташовувалася на території Київського, а не Волинського, воєводства.

Первинні поборові реєстри 1569 - 1570 рр. служили основою створення сумація 1570 р. Останній містить свідчення про вибирання податку з майже 50 волинських міст, а також фіксує власників, котрі його не сплатили. До останніх віднесено й кн. Романа Сангушка, який володів містами Турійськ, 
Несухоїжі, Звинигород з волостями, а також безміською Чернечгородською волостю. Відповідно, ці маєтності не знайшли представлення в сумарії. Це, можливо, було пов'язано з тим, що на рубежі 1569 та 1570 рр., коли й збирався та вручався поборці податок, він перебував за межами своїх волинських володінь, оскільки був задіяний у військових діях і лише згодом зміг організувати збір державного податку. Очевидно, саму суму побору та відповідну документацію було передано до Скарбу пізніше, через що вона до сумарного волинського реєстру і не потрапила.

Сумарій 1570 р. відобразив не тільки стан маєтностей, в тому числі й характеристики міських поселень, але й рівень податкової культури шляхти та поборців. Його свідчення $\epsilon$ важливими з точки зору того, що вони є рубіжними для розгляду урбанізаційних процесів на території Волині до і після Люблінської унії. В той же час, як урбанізаційний рубіж для Волині (як і для інших воєводств, які були інкорпоровані Польщею) розглядається кінець XV ст. [11, с. 34; 20, с. 212 - 215] На час Люблінської унії П.М. Сас нараховує на Волині 121 міське поселення [20, с. 212 - 215]. Серед них лише трохи більше чверті (32) дослідник відносить до міст - крупних та малих.

Наявність свідчень про характеристики ряду міських поселень у первинних та підсумкових реєстрах дає можливість порівняння свідчень, а також розгляду відмінностей у характері інформації. Така можливість існує для незначної частини міст на 1570 р. Подані в додатку первинні реєстри дають таку можливість для двох поселень, які відносяться до малих міст чи й містечок. Вони, до речі, в сумарії були включені до маєтків, з яких побор було подано із запізненням [30, s. 31 - 32]. Так, на прикладі Коблина можна побачити недостатньо розвинуте поселення міського характеру. В реєстрі відсутні згадки про ремісників. Сама ж структура поселення містить лише натяки на міську організацію, можливо близьку до села, в якому проведено впорядкування землекористування (поміру). Про те, що власник намагався перетворити поселення у міське може свідчити незначне задіяння населення у землеробстві - переважна більшість міщан мала в користуванні виключно городи. Кількісні показники за чисельністю оподатковуваних категорій у обох різновидах реєстрів співпадають за винятком відсутності у сумарії даних про пустки, яких первинний реєстр фіксує шість. При цьому первинний реєстр, чого також немає у сумарії, фіксує досить значну кількість сільських поселень, належачих власнику Коблина. Між первинним та сумарним реєстрами Жукова помітні деякі відмінності, але такі характерні не тільки для цього міста і подібні випадки вимагають окремого розгляду. Сумарії не фіксують господарств, які належали жінкам, скоріше за все вдовам, а первинні реєстри три такі випадки (два у Жукові та один у Коблині) зазначають.

Таким чином, можна говорити про те, що навіть на прикладі окремих маєтностей видно важливість первинних поборових реєстрів як історичних джерел. В цілому ряді випадків вони узгоджуються зі свідченнями сумаріїв, а от суперечності в їх свідченнях вимагають спеціального вивчення. Це може внести окремі корективи і у вивчення системи збирання податків на території Волині у перше десятиріччя після Люблінської унії, коли як шляхта, так і поборці лише включалися в систему достатньо регулярного державного оподаткування.

\section{Додаток. Документи}

Реестръ выбиран п побору

на соиме Любельском уфаленог з ыменя его млсти пна Михала Дчалынского подкоморего хелменског старосты земли Добрынское Фтдан ест черезъ мене Миика Селивестровича

Место Жуковъ

Наперве $u$ домов рынковыхъ по гр д, з роли по гр i, а $з$ огорода по гр а

Сицко

Серко

Сергеи

Ярося

Жукъ

Мишко 
Хомица

Ступа

Петрь

Вербило

Санюкъ

Сенеи

Миколаи

Карпина

Домы уличные с которы $x$ по гр в, с поля по гр i, з огорода по гр а

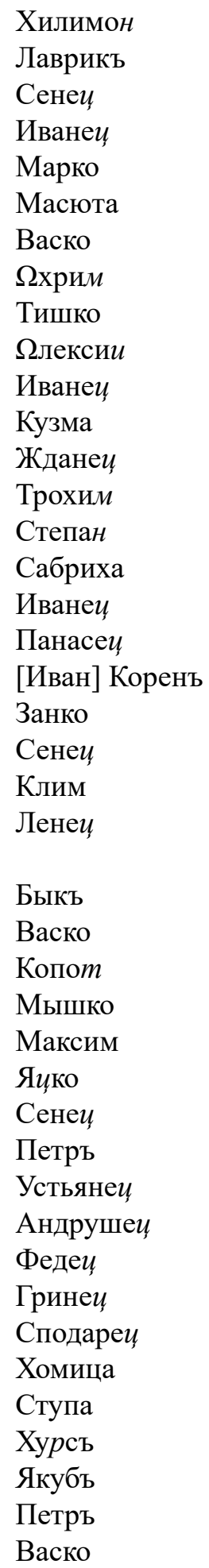


Воитехъ

Семеновчик

Викгурчая

Блажеико

Панасе $\underline{\text { С }}$

Сене

Васко

Миколаи

Иванеи

Лнинка

Ремесники с которых по гр д

Копот Ковал

Ллексиец Кравец

Васко Чоботар

囚городники местские по гр д

Ллексии

Пилипеи

Сенеи

Степан

Иванеу

Лниско

Федеи

Ган

Карповая

Лико

Игнат

Иванець

Демид

Лниско

Левко

Петрь

Микита

Параска

Феде $y$

Щасны $u$

С колъ млыновыхъ аі по гр кд

Котлов горелчаных аi по гр кд

Центральний державний історичний архів України, м. Київ. Ф. 44 «Вінницький гродський суд». Оп. 1. Спр. 1. Арк. 155 - 156 зв. 
Реестръ подымщизны его кр мл уфаленое на соиме валном Любелском в року [] его м(и)л(о)сти пна Яна Монтовта Коблинског в року о з дыму по і гршеи а $з$ огородников по два гр а з местечка Коблина $з$ дымов по гр в а з огородников по а гр которы $u$ поле мают по і грше $u$

\begin{tabular}{|c|c|c|c|c|}
\hline \multirow[b]{2}{*}{ Янко } & \multicolumn{3}{|c|}{ домы и огородыl поле } & \\
\hline & $\Gamma p$ в & $\mathrm{a}$ & $\mathrm{i}$ & \\
\hline Грицко & $г p$ в & $\mathrm{a}$ & & \\
\hline Игнат & $г p$ в & $\mathrm{a}$ & & \\
\hline Левко & $г p$ в & $\mathrm{a}$ & & \\
\hline Андруико & $г p$ в & $\mathrm{a}$ & & \\
\hline \multirow[t]{2}{*}{ Жданец } & $г p$ в & $\mathrm{a}$ & & \\
\hline & & & & Другая полать \\
\hline Масина & $г p$ в & $\mathrm{a}$ & $\mathrm{i}$ & \\
\hline Юзефь & $г p$ в & $\mathrm{a}$ & & \\
\hline Савосткова & гр в & $\mathrm{a}$ & & \\
\hline Матве $u$ & $г p$ в & $\mathrm{a}$ & & \\
\hline Ста[сич] & $г p$ в & $\mathrm{a}$ & & \\
\hline Клишъ & $г p$ в & $\mathrm{a}$ & & \\
\hline Кузма & $г p$ в & $\mathrm{a}$ & & \\
\hline Гриццко & $г p$ в & $\mathrm{a}$ & $\mathrm{i}$ & \\
\hline [МатАшъ] & $г p$ в & $\mathrm{a}$ & & \\
\hline Филип & $г p$ в & $\mathrm{a}$ & & \\
\hline Свирид & $г p$ в & $\mathrm{a}$ & $\mathrm{i}$ & \\
\hline
\end{tabular}

Сума дымов зі

Лгородников зі

Пол г

домы огород поле $u$

$\begin{array}{lll}\text { Волошка } & \text { в } & \text { a } \\ \text { Дмитръ } & \text { в } & \mathrm{a} \\ \text { Фицко } & \text { в } & \mathrm{a} \\ \text { Левошович } & \text { в } & \mathrm{a} \\ \text { Полудворанин в } & \\ \text { Степане } е & \text { в } & \\ \text { Никчемны } u & \text { в } & \\ \text { Жилка } & \text { в } & \\ \text { Андрђець } & \text { в } & \mathrm{a} \\ \text { Лучка } & \text { в } & \mathrm{a} \\ \text { Лысы } u & \text { в } & \\ \text { Бурис } & \text { в } & \\ \text { Иване } и & \text { в } & \end{array}$

Пустокъ s

В томъ местечку а корчма гр ві

$\Omega$ т шинку гр $\mathrm{s}$

Центральний державний історичний архів України, м. Київ. Ф. 44 «Вінницький гродський суд». Оп. 1. Спр. 1. Арк. 181 - 181 зв. 


\section{Список використаних джерел та літератури}

1. Архив Юго-Западной России. Киев, 1886. Ч. VII. T. 1.

2. Атаманенко В. Описи поліських маєтностей кн. Романа Сангушка 1569 р. Минуле і сучасне Волині та Полісся. Сереховичі та Старовижівщина в історії Украӥни, Волині та Полісся. Київ, 2006. Вип.21. С. 217 - 229.

3. Атаманенко В. Описи волинських маєтків князів Чорторийських XVI ст. Минуле і сучасне Волині та Полісся. Луцьк, 2010. Вип. 37. С. $318-327$.

4. Атаманенко В.Б. Описово-статистичні джерела другої половини - першої половини з історії Старокостянтинова. Болохівщина: Осягнення історії. Старокостянтинів, 2009. Ч. 1. С. 84 - 95.

5. Атаманенко В.Б. Свідчення про татарські напади на Волинь у луцьких гродських книгах другої половини XVI ст. Матеріали I - III науково-краєзнавчих конференцій «Остріг на порозі 900-річчя» (1990 - 1992). Остріг, 1992. Ч. 1. C. $13-14$.

6. Атаманенко В.Б. Вірогідність поборових документів XVI століття. Дніпропетровський історико-археографічний збірник. Дніпропетровськ, 1996. Вип. 1. С. $49-58$.

7. Баранович О.І. Залюднення України перед Хмельниччиною: Волинське воєводство. Київ, 1930. 155 с.

8. Ерусалимский К.Ю. Реестр налоговых выплат с Ковеля и Ковельской волости 1576 г. Вестник Университета Дмитрия Пожарского. Москва, 2017. №2 (6). С. 248 - 323.

9. Исаевич Я.Д. Гродские и земские акты - важнейший источник по истории аграрных отношений в Речи Посполитой в XVI - XVII в. Ежегодник по аграрной истории Восточной Европьл. 1961 г. Рига, 1963. С. 90 - 99.

10. Заяць А.С. Пожежі в місттах Волині XVI - першої половини XVII ст (за архівними джерелами) Шоста Всеукраїнська наукова конференція з історичного краєзнавства. Луцьк, 1993. С. 417.

11. Заяць А.С. Урбанізаційний процес на Волині в XVI - першій половині XVII століття. Львів, 2003. 205 с.

12. Матеріали до історії Острозької академії (1576 - 1636). Бібліографічний довідник. Київ, 1990. 217 с.

13. Кіку I.О. Актові книги як джерело для вивчення демографії Волині першої половини XVII ст. Icmopuчнi дослідження: Вітчизняна історія. Київ, 1985. С. 51 - 52.

14. Кісь Я.П. Аграрні відносини в містах Руського і Белзького воєводств у XVI-XVIIст. Питання соиіальноекономічної історії. Львів, 1978. Вип. 14. С. 90 - 95.

15. Крикун М.Г. Чисельність населення Волинського воєводства у першій половині XVII ст. Вісник Львівського університету: Серія історична. Львів, 1988. Вип. 24. С. $71-81$.

16. Крикун М.Г. Масові статистичні джерела до історії Правобережної Україні!XVI-XVIII ст. Українська археографія: сучасний стан та перспективи розвитку. Київ, 1988. С.77.

17. Крикун М.Г. Подимні реєстри XVII ст. як джерело. Третя республіканська наукова конференція з архівознавства та інших спеціальних історичних дисциплін. Друга секція: Спеціальні історичні дисципліни. Київ, 1968. С. $69-98$.

18. Крикун М.Г. Источники и историография демографического состояния Правобережной Украины накануне и во время Освободительной войны украинского народа 1648-1654 гг. Проблемы историографии и источниковедения истории СССР. Днепропетровск, 1979. С. 126 - 137.

19. Копысский Б.З. Рукописные книги гродских и земских судов как источник по истории крестьянства Белоруссии Белороссика: Кннговедение, источники, библиография. Минск, 1980. С. 91 - 102.

20. Сас П.М. Феодальные города Украины в конце XV - 60-х годах XVI в. Киев, 1989. 232 с.

21. Описи Острожчини другої половини XVI - першої половини XVII століття. Київ; Острог; Нью-Йорк, 2004. 383 c.

22. ЦДІАУК (Центральний державний історичний архів України, м. Київ). Ф. 25: Луцький гродський суд. Оп. 1. - Од. зб. 1. 863 арк.

23. ЦДІАУК. Ф. 44 «Вінницький гродський суд». Оп. 1. Од. зб. 1. 886 арк.

24. Archiwum Główne Akt Dawnych w Warszawie. Archiwum Skarbu Koronnego. - №31. 150 k.

25. Atlas Źródeł i Materiałów do Dziejów Dawnej Polski, 2015, №2.

26. Atlas Źródeł i Materiałów do Dziejów Dawnej Polski. 2015, №3.

27. Boroda K. O przydatności rejestrów poborowych z XVI wieku w badaniach demograficznych. Przeszłość Demograficzna Polski. Warszawa, 2014. №33. S. 21 - 38.

28. Gochna M. Elektroniczna edycja rejestrów poborowych województwa kaliskiego z drugiej połowy XVI w. Studia Geohistorica. Rocznik historyczno-geograficzny. Warszawa, 2014. Z. 2. S. 143-150.

29. Giejsztorowa I. Źródła i szacunki w badaniach osadnictwa i demografii Polski XVI i XVII w. Kwartalnik historii kultury materialnej. Warszawa, 1962. R. X. №3 - 4. S. $575-584$.

30. Zródła dziejowe. Warszawa, 1889. T. XIX. 485.

31. Volumina legum. Petersburg, 1859. T. II. XIII+482.

\section{References}

1. Arkhiv Yugo-Zapadnoy Rossii. Kiev, 1886. Ch. VII. T. 1. [in Russian].

2. Atamanenko V. Opysy poliskykh maietnostei kn. Romana Sanhushka 1569 r. Mynule i suchasne Volyni ta Polissia. Serekhovychi ta Starovyzhivshchyna v istorii Ukrainy, Volyni ta Polissia. Kyiv, 2006. Vyp.21. S. $217-229$. [in Ukrainian].

3. Atamanenko V. Opysy volynskykh maietkiv kniaziv Chortoryiskykh XVI st. Mynule i suchasne Volyni ta Polissia. Lutsk, 2010. Vyp. 37. S. 318 - 327. [in Ukrainian].

4. Atamanenko V.B. Opysovo-statystychni dzherela druhoi polovyny-pershoi polovyny z istorii Starokostiantynova. Bolokhivshchyna: Osiahnennia istorii. Starokostiantyniv, 2009. Ch. 1. S. 84 - 95. [in Ukrainian]. 
5. Atamanenko V.B. Svidchennia pro tatarski napady na Volyn u lutskykh hrodskykh knyhakh druhoi polovyny XVI st. Materialy I - III naukovo-kraieznavchykh konferentsii "Ostrih na porozi 900-richchia" (1990 - 1992). Ostrih, 1992. Ch. 1. S. 13 - 14. [in Ukrainian].

6. Atamanenko V.B. Virohidnist poborovykh dokumentiv XVI stolittia. Dnipropetrovskyi istoryko-arkheohrafichnyi zbirnyk. Dnipropetrovsk, 1996. Vyp. 1. S. 49 - 58. [in Ukrainian].

7. Baranovych O.I. Zaliudnennia Ukrainy pered Khmelnychchynoiu: Volynske voievodstvo. K., 1930. 155 s. [in Ukrainian].

8. Erusalimskiy K.Yu. Reestr nalogovykh vyplat s Kovelya i Kovel'skoy volosti 1576 g. Vestnik Universiteta Dmitriya Pozharskogo. Moskva, 2017. №2 (6). S. 248 - 323. [in Russian].

9. Isaevich Ya.D. Grodskie i zemskie akty - vazhneyshiy istochnik po istorii agrarnykh otnosheniy v Rechi Pospolitoy v XVI - XVII v. Ezhegodnik po agrarnoy istorii Vostochnoy Evropy. 1961 g. Riga, 1963. S. 90 - 99. [in Russian].

10. Zaiats A.Ie. Pozhezhi v misttakh Volyni XVI - pershoi polovyny XVII st (za arkhivnymy dzherelamy) Shosta Vseukrainska naukova konferentsiia z istorychnoho kraieznavstva. Lutsk, 1993. S. 417. [in Ukrainian].

11. Zaiats A. Urbanizatsiinyi protses na Volyni v XVI - pershii polovyni XVII stolittia. Lviv, 2003. 205 s. [in Ukrainian].

12. Materialy do istorii Ostrozkoi akademii (1576 - 1636). Bliohrafichnyi dovidnyk. Kyiv, 1990. 217 s. [in Ukrainian].

13. Kiku I.O. Aktovi knyhy yak dzherelo dlia vyvchennia demohrafii Volyni pershoi polovyny XVII st. Istorychni doslidzhennia: Vitchyzniana istoriia. Kyiv, 1985. S. 51 - 52. [in Ukrainian].

14. Kis Ya.P. Ahrarni vidnosyny v mistakh Ruskoho i Belzkoho voievodstv u XVI-XVII st. Pytannia sotsialnoekonomichnoi istorii. Lviv, 1978. Vyp. 14. S. 90 - 95. [in Ukrainian].

15. Krykun M.H. Chyselnist naselennia Volynskoho voievodstva u pershii polovyni XVII st. Visnyk Lvivskoho universytetu: Seriia istorychna. Lviv, 1988. Vyp. 24. S. 71 - 81. [in Ukrainian].

16. Krykun M.H. Masovi statystychni dzherela do istorii Pravoberezhnoi Ukraini XVI-XVIII st. Ukrainska arkheohrafiia: suchasnyi stan ta perspektyvy rozvytku. Kyiv, 1988. S.77. [in Ukrainian].

17. Krykun M.H. Podymni reiestry XVII st. yak dzherelo. Tretia respublikanska naukova konferentsiia $\mathrm{z}$ arkhivoznavstva ta inshykh spetsialnykh istorychnykh dystsyplin. Druha sektsiia: Spetsialni istorychni dystsypliny. Kyiv, 1968. S. 69 - 98. [in Ukrainian].

18. Krykun M.H. Istochniki i istoryohrafiia demohraficheskoho sostoianiia Pravoberezhnoi Ukrainy nakanune i vo vremia Osvoboditelnoi voiny ukrainskoho naroda 1648-1654 hh. Problemy istoryohrafii i istochnykovedeniia istorii SSSR. Dnepropetrovsk, 1979. S. 126 - 137. [in Russian].

19. Kopysskii B.Z. Rukopisnye knihi hrodskikh i zemskikh sudov kak istochnik po istorii krestianstva Belorussii Belorossyka: Knihovedenie, istochniki, bibliohrafiia. Minsk, 1980. S. 91 - 102. [in Russian].

20. Sas P.M. Feodalnye horoda Ukrainy v kontse XV - 60-kh hodakh XVI v. Kiiev, 1989. 232 s. [in Russian].

21. Opysy Ostrozhchyny druhoi polovyny XVI - pershoi polovyny XVII stolittia. Kyiv; Ostroh; Niu-York, 2004. 383 s. [in Ukrainian].

22. TsDIAUK (Tsentralnyi derzhavnyi istorychnyi arkhiv, m. Kyiv). F. 25: Lutskyi hrodskyi sud. Op. 1. Od. zb. 41. 863 ark. [in Ukrainian].

23. TsDIAUK. F. 44 «Vinnytskyi hrodskyi sud». Op. 1. Od. zb. 1.886 ark. [in Ukrainian].

24. Archiwum Główne Akt Dawnych w Warszawie. Archiwum Skarbu Koronnego. - №31. 150 k. [in Ukrainian].

25. Atlas Źródeł i Materiałów do Dziejów Dawnej Polski, 2015, №2. [in Polish].

26. Atlas Źródeł i Materiałów do Dziejów Dawnej Polski. 2015, №3. [in Polish].

27. Boroda K. O przydatności rejestrów poborowych z XVI wieku w badaniach demograficznych. Przeszłość Demograficzna Polski. Warszawa, 2014. №33. S. 21 - 38. [in Polish].

28. Gochna M. Elektroniczna edycja rejestrów poborowych województwa kaliskiego z drugiej połowy XVI w. Studia Geohistorica. Rocznik historyczno-geograficzny. Warszawa, 2014. Z. 2. S. 143-150. [in Polish].

29. Giejsztorowa I. Źródła i szacunki w badaniach osadnictwa i demografii Polski XVI i XVII w. Kwartalnik historii kultury materialnej. Warszawa, 1962. R. X. №3-4. S. 575-584. [in Polish].

30. Źródła dziejowe. Warszawa, 1889. T. XIX. 485. [in Polish].

31. Volumina legum. Petersburg, 1859. T. II. XIII+482. [in Polish]. 